\title{
ANALISIS LOGIT KEPUTUSAN PERILAKU ILLEGAL FISHING NELAYAN PELABUHAN PERIKANAN NUSANTARA BRONDONG JAWA TIMUR
}

\author{
(DECISION MAKING LOGIT ANALYSIS ON ILLEGAL FISHING BEHAVIOR)
}

\author{
Clara Tiwiw ${ }^{1}$, Daniel R. Monintja ${ }^{2}$, Akhmad Fauzi ${ }^{3}$, Kadarwan Soewardi ${ }^{4}$, Victor P.H. Nikijuluw ${ }^{5}$ \\ 1 Corresponding author \\ ${ }^{2}$ Staf Departemen Pemanfaatan Sumberdaya Perikanan, FPIK - IPB \\ ${ }^{3}$ Staf Fakultas Ekonomi Manajemen IPB \\ ${ }^{4}$ Staf DepartemenBudidaya Perikanan, FPIK - IPB \\ ${ }^{5}$ P2SDKP Kementerian Kelautan Perikanan \\ E-mail : tiwowclara@yahoo.co.id
}

\begin{abstract}
Illegal fishing activities are basically not just done by foreign fisherman but also carried out by fisherman of Indonesia but they are using the size are smaller that is under 30 gross tonage. Due to the size a small fishing vessels are often allowed by the law enforcement officers due to the influence that is relatively small, whereas in the number of ships that are much smaller of course though its capacity would provide a major problem for the management of fish resources in Indonesia. Fishermen who settled in Brondong East Java is an example of illegal fishing activities as offeriders by loweinr the size of the ship that is lowering the gross tonage. These activities were carried out because the cost of maintaining a very troublesome permission and expensive.
\end{abstract}

Keywords: Model logit, compliance, PPN Brondong

\begin{abstract}
ABSTRAK
Kegiatan illegal fishing pada dasarnya tidak saja dilakukan oleh nelayan asing tetapi juga dilakukan oleh nelayannelayan Indonesia dengan ukuran kapal yang relatif kecil yaitu dibawah 30 Gross Tone (GT). Ukuran kapal yang kecil lepas dari analisis kegiatan ilegal, padahal dalam jumlah kapal yang banyak dengan kapasitas yang kecil tentu akan memberikan masalah besar bagi pengelolaan sumber daya ikan di Indonesia. Nelayan yang bermukim di Brondong Jawa Timur merupakan salah satu contoh yang lebih memiliki untuk melakukan kegiatan illegal fishing dengan menurunkan ukuran kapal yaitu menurunkan GT. Kegiatan penangkapan ikan secara ilegal dilakukan karena beban ekonomi untuk pengurusan yang cukup tinggi dan tata cara pemgurusan perijinan yang sangat merepotkan merupakan alasan utama nelayan Brondong.
\end{abstract}

Kata kunci: Model logit, kepatuhan, PPN Brondong

\section{PENDAHULUAN}

\subsection{Latar Belakang}

Pencurian ikan terutama oleh kapal asing merupakan salah satu kegiatan IUU Fishing yang menjadi perhatian pemerintah khususnya Kementerian Kelautan dan Perikanan, karena kerugian Negara akibat kegiatan ini relatif besar. Selain hilangnya PDB, ada juga pendapatan aktual yang hilang yang bisa diperoleh Indonesia sebagai Negara Kepulauan, pendapatan itu adalah dalam bentuk biaya tambat, biaya izin kapal, pajak, dan pungutan lainnya sesuai dengan ketentuan hukum (MRAG 2005). Selain pencurian ikan oleh kapal penangkap ikan asing, kegiatan illegal fishing yang dilakukan oleh nelayannelayan Indonesia dengan ukuran kapal dibawah 30 GT juga perlu diperhatikan.

Memang kapasitas kapal penangkap tersebut tidak sebesar kapal-kapal asing yang melakukan illegal fishing, namun karena jumlah kapal penangkap ikan dibawah 30 Gross Tone (GT) mempunyai jumlah yang banyak yaitu menurut statistik perikanan tangkap pada tahun 2009 jumlah kapal tersebut sebanyak 153.580 unit atau sebesar 96,03 \% dari seluruh jumlah kapal di Indonesia. Jumlah kapal dengan kapasitas yang kecil ini tentunya akan memberikan masalah yang besar bagi pengelolaan sumber daya perikanan di Indonesia (law of big numbers).

Pelabuhan Brondong merupakan salah satu pelabuhan perikanan nusantara dengan jumlah domisili kapal yang cukup banyak yaitu sebesar 1.875 buah kapal (PIPP 2011), dan dengan kapasitas kapal mayoritas dibawah 30 GT.

PPN Brondong dipilih sebagai tempat penelitian karena merupakan pelabuhan dengan intensitas keluar masuk kapal yang cukup padat, menurut statistik tahun 2010 di PPN Brondong rata-rata kapal yang masuk ke 
Pelabuhan ini adalah $52 \mathrm{kapal} / \mathrm{hari}$. Dengan intensitas keluar-masuk kapal ini kegiatan illegal fishing yang dilakukan nelayan di daerah ini pun banyak tejadi. Kegiatan illegal fishing yang terjadi di daerah ini mayoritas yang berhubungan dengan ketidaklengkapan perizinan kapal penangkap ikan, dan penangkapan ikan dengan izin palsu dengan cara menurunkan GT kapal (downsizing GT). Kegiatan illegal fishing yang dilakukan nelayan di PPN Brondong merupakan suatu perilaku ekonomi dari pilihan masing-masing nelayan. Untuk mengetahui bagaimana hubungan antara perilaku illegal fishing nelayan dan variabel-variabel yang mempengaruhinya digunakan model logit (regresi logistik) dimana metode ini merupakan analisis statistika yang mendeskripsikan hubungan antara peubah respon yang memiliki dua kategori atau lebih peubah penjelas berskala kategori atau interval (Hosmer dan Lemeshow 2000).

\subsection{Tujuan Penelitian}

Penelitian ini bertujuan untuk: (1) mengetahui karakteristik nelayan Brondong Jawa Timur; (2) mengetahui jenis alat yang digunakan dalam penangkapan ikan; dan (3) menganalisis peubah-peubah yang berpengaruh terhadap pengambilan keputusan nelayan Brondong Jawa Timur dalam melakukan kegiatan illegal fihisng.

\section{METODE PENELITIAN}

\subsection{Lokasi dan Waktu Penelitian}

Penelitian ini dilakukan di Pelabuhan Perikanan Nusantara Brondong Jawa Timur yang dimulai pada bulan Januari 2011 sampai dengan Juni 2011.

\subsection{Metode Analisis Data}

Metode yang digunakan dalam penelitian ini adalah model logit (regresi logistik). Model logit ini digunakan karena peubah respon (dependent variable) dalam model ini bersifat kualitatif dengan skala pengukuran nominal atau ordinal. Nilai -nilai peubah respon kualitatif ini bersifat terbatas atau limited dependent variable (Juanda, 2009) dengan mempunyai dua kemungkinan (peubah biner) yaitu melakukan kegiatan illegal fishing $(\mathrm{Y}=1)$ atau tidak. $(\mathrm{Y}=0)$. Dalam suatu objek penelitian, kondisi dengan 2 kategori tersebut mengakibatkan Y berdistribusi Bernoulli. Fungsi distribusi peluang untuk $y$ dengan parameter $Y$ adalah $P(Y=y)=\gamma^{y}(1-\gamma)^{1-y}$ dengan $\mathrm{y}=0,1$. Sehingga akan didapatkan probabilitas masing-masing kategori adalah $P(Y=1)=\gamma \quad$ dan $\quad P(Y=0)=1-\gamma$ dengan $E(y)=\gamma, 0 \leq \gamma \leq 1$. Secara umum model probabilitas regresi logistik dengan melibatkan beberapa variabel bebas $(x)$ dapat diformulasikan sebagai berikut :

$E(y \mid x)=\frac{e^{\left(\beta_{0}+\beta_{1} x_{1}+\beta_{2} x_{2}+\ldots .+\beta_{p} x_{p}\right)}}{1+e^{\left(\beta_{0}+\beta_{1} x_{1}+\beta_{2} x_{2}+\ldots+\beta_{p} x_{p}\right)}}$

Fungsi $Y(x)$ merupakan fungsi non-linear sehingga perlu dilakukan transformasi logit untuk memperoleh fungsi linear agar dapat dilihat hubungan antara variabel respon $(y)$ dengan variabel prediktornya $(x)$. Bentuk logit dari $Y(x)$ dinyatakan sebagai $g(x)$, yaitu:

$g(x)=\ln \left(\frac{\gamma(x)}{1-\gamma(x)}\right)$

Persamaan (1) kemudian disubstitusikan ke persamaan (2) sehingga menghasilkan $\ln \left(\frac{\gamma(x)}{1-\gamma(x)}\right)+\beta_{0}+\beta_{1} x_{1}+\beta_{2} x_{2}+\ldots+\beta_{p} x_{p}$

Pendugaan parameter koefisien Model logit umunya menggunakan penduga kemungkinan maksimum atau maximum likelihood (ML) estimator (Juanda 2009). Metode ML ini pada dasarnya memberikan nilai estimasi parameter $\beta$ dengan cara memaksimumkan fungsi likelihood-nya. Jika fungsi distribusi peluang untuk $y_{i}$ adalah $f\left(y_{i}\right)=\gamma^{y_{i}}(1-\gamma)^{1-y_{i}}, \quad$ maka fungsi likelihood untuk $\mathrm{n}$ pengamatan independen adalah sebagai berikut :

$$
\begin{aligned}
& L\left(\beta_{0}, \beta_{1}, \beta_{2}, \ldots, \beta_{p}\right)=\prod_{i=1}^{n}\left\{\left[\gamma\left(x_{i}\right)\right]^{y_{i}}\left[1-\gamma\left(x_{i}\right)\right]^{1-y_{i}}\right\} \\
& =\prod_{i=1}^{n}\left\{\left[\frac{\gamma\left(x_{i}\right)}{1-\gamma\left(x_{i}\right)}\right]^{y_{i}}\left[1-\gamma\left(x_{i}\right)\right]\right\}
\end{aligned}
$$




$$
=\left[\frac{\gamma\left(x_{i}\right)}{1-\gamma\left(x_{i}\right)}\right]^{\sum_{i=1}^{n} y_{i}}\left[1-\gamma\left(x_{i}\right)\right]^{n}
$$

Berdasarkan fungsi likelihood didapatkan In fungsi likelihood-nya sebagai berikut :

$$
\begin{aligned}
\ln \left(L\left(\beta_{0}, \beta_{1}, \beta_{2}, \ldots, \beta_{p}\right)\right) & =\ell\left(\beta_{0}, \beta_{1}, \beta_{2}, \ldots, \beta_{p}\right) \\
& =\ln \left\{\prod_{i=1}^{n}\left\{\left[\frac{\gamma\left(x_{1}\right)}{1-\gamma\left(x_{1}\right)}\right]^{y_{1}}\left[1-\gamma\left(x_{1}\right)\right]\right\}\right\}
\end{aligned}
$$

Adapun variabel - variabel bebas yang digunakan dalam penelitian ini yang diduga mempengaruhi probabilitas responden melakukan illegal fishing adalah biaya melaut (X $\mathrm{X}_{\text {biayaops), Ukuran }}$ GT sebenarnya $\left(\mathrm{X}_{\mathrm{GT}}\right)$, variabel sosial ekonomi : umur ( $\left.\mathrm{X}_{\mathrm{UMUR}}\right)$, pendidikan (X $\left.\mathrm{XDD}_{\mathrm{PD}}\right)$, dan Pengalaman $\left(\mathrm{X}_{\mathrm{dPENG}}\right)$, dan jenis alat tangkap ( $\left.\mathrm{X}_{\text {dAlatTAngkap }}\right)$. Ada dua model yang dianalisis dalam penelitian ini. Pada model pertama variabel bebas yang digunakan hanya biaya melaut (X $\mathrm{X}_{\text {biayaops }}$ ), Ukuran GT sebenarnya $\left(\mathrm{X}_{\mathrm{GT}}\right)$, dan jenis alat tangkap ( $\left.\mathrm{X}_{\text {dAlatTangkap}}\right)$, sedangkan pada model kedua dimasukan juga variabel sosial ekonomi. Berikut formula logit model dalam penelitian ini :

Model 1:

$$
\begin{gathered}
Y=\beta_{0}+\beta_{1} X_{\text {BiayaOps }}+\beta_{2} X_{G T}+\beta_{3} X_{\text {dAlatTangkap }} \\
\text { Model } 2: \\
Y=\beta_{0}+\beta_{1} X_{\text {BiayaOps }}+\beta_{2} X_{G T}+\beta_{3} X_{U M U R}+\beta_{4} X_{P D D}+\beta_{5} X_{P E N G}+\beta_{6} X_{\text {dAlatTangkap }}
\end{gathered}
$$

dimana :

BiayaOps : Biaya operasional melaut (Juta rupiah/trip)

GT : Ukuran GT sebenarnya (GT)

Umur : Umur responden (dalam Tahun)

PDD : Lamanya pendidikan yang ditempuh responden (dalam Tahun)

PENG : Lamanya pengalaman responden menjadi nelayan (dalam Tahun)

dAlatTangkap : Variabel dummy alat tangkap, diberi nilai 1 jika alat tangkap yang

digunakan responden adalah cantrang (dogol), diberi nilai 2 jika alat tangkap yang digunakan purse seine, dan nilai 3 jika alat tangkap yang digunakan adalah pancing rawai.

\section{HASIL DAN PEMBAHASAN}

\subsection{Karakteristik Responden}

Ilegal fishing yang dilakukan oleh nelayan-nelayan Indonesia sendiri (dengan GT rendah) tentunya akan merugikan negara dan juga sumber daya ikan di Indonesia. Memang kapasitas kapal tidak sebesar Kapal-kapal asing yang melakukan illegal fishing, namun karena jumlah kapal yang banyak tentunya akan mengakibatkan masalah (law of big number). Survei lapangan untuk mengetahui kecendrungan perilaku illegal fishing dilakukan pada 105 responden, dimana responden yang diambil adalah responden yang menggunakan alat tangkap cantrang (dogol), purse seine dan pancing. Karaktersitik dari nelayan yang dijadikan sebagai responden di Pelabuhan Perikanan Nasional Brondong yang dibagi berdasarkan jenis alat tangkap dapat dilihat pada Tabel 1 .
Pada Tabel 1 menunjukkan bahwa rata-rata ukuran GT kapal responden adalah 15,79 GT dan berkisar antara GT 6 - 29, rata-rata ukuran GT alat tangkap cantrang (dogol) adalah 16,29 GT, ukuran GT kapal purse seine adalah 17 , 72 GT dan rata-rata ukuran GT pancing adalah yang terkecil yaitu 8,31. Ukuran GT pancing lebih kecil dibandingkan yang lainnya karena jumlah tangkapan alat tangkap pancing lebih sedikit dibandingkan alat tangkap lainnya dalam satu kali trip. Biaya Operasional paling besar adalah alat tangkap cantrang (dogol) karena lama melaut alat tangkap ini lebih lama yaitu berkisar 10-14 hari, dibandingkan alat purse seine (1-10 hari), dan pancing 8-10 hari dan juga pengaruh dari ukuran GT kapal dan jumlah ABK. Umur responden mempunyai rata-rata 43,47 tahun, responden alat tangkap purse seine mempunyai rata-rata umur yang lebih besar (44,53 tahun) dibandingkan dengan alat tangkap cantrang $(44,45$ 
tahun) dan alat tangkap pancing $(36,31$ tahun). Rata- rata pendidikan yang ditempuh responden adalah 6,92 tahun atau hanya lulusan $\mathrm{SD}$, rata-rata pendidikan alat tangkap cantrang dan purse seine adalah lulusan SD atau 6 tahun, sedangkan responden dengan alat tangkap pancing adalah 9 tahun atau lulus SMP. Sedangkan pengalaman responden rata-rata alat tangkap cantrang dan purse seine tidak berbeda jauh yaitu sebesar 24,04 tahun dan 24,83 tahun, reponden dengan alat tangkap pancing mempunyai pengalaman yang lebih sedikit yaitu 16,54 tahun.

\subsection{Distribusi Alat Tangkap}

Kegiatan illegal fishing yang dilakukan di PPN Brondong rata-rata adalah penurunan GT pada surat izin (downsizing) dan tidak mempunyai surat izin. Alasan dilakukan penurunan GT adalah karena dengan ukuran dibawah 10 GT, surat izin tidak perlu diurus sampai ke provinsi, cukup hanya sampai kabupaten saja, dan waktu yang diperlukan pun relatif singkat hanya 1 hari dan biaya yang murah yaitu sebesar 50 ribu sampai dengan 300 ribu termasuk dengan ongkos pulang pergi dari Brondong ke Kota Lamongan. Alasan lain tidak patuh (non compliance) yang diungkapkan responden adalah karena 'ribet' atau menyulitkan (complicated) nelayan karena banyak persyaratan yang harus dipenuhi sedangkan jika tidak melaut waktu yang mereka gunakan adalah untuk memperbaiki jaring dan kapal. Adapun nelayan yang tetap patuh menggunakan jasa pihak ketiga dalam mengurusi izin, sehingga biaya yang dikeluarkanpun tidak sedikit yaitu dua sampai tiga juta. Berikut keragaan responden nelayan terhadap kepatuhan (compliance) terhadap peraturan.

Jumlah responden nelayan yang melakukan kegiatan illegal fishing atau tidak patuh terhadap peraturan ada sebanyak 62 orang atau $59 \%$ dari total responden, sedangkan sisanya yaitu 41 $\%$ adalah responden yang patuh terhadap peraturan (tidak melakukan kegiatan illegal). Jika dirinci berdasarkan alat tangkap, kecendrungan perilaku illegal fishing terbanyak adalah nelayan yang menggunakan alat tangkap cantrang yaitu sebesar $77 \%$ (43 orang dari 56 orang responden), sedangkan hampir setengahnya $(47 \%)$ responden nelayan alat tangkap purse seine melakukan kegiatan illegal fishing, responden yang menggunakan alat tangkap pancing relatif lebih sedikit yang melakukan kegiatan illegal fishing, yaitu hanya sebesar $15 \%$ dari keseluruhan responden yang menggunakan alat tangkap ini. Presentase keputusan melakukan kegiatan illegal fishing dari responden berdasarkan alat tangkap dapat dilihat pada Gambar 1,2 dan Gambar 3.

Tabel 1. Karakterisitik responden

\begin{tabular}{|l|c|c|c|c|c|}
\hline \multirow{2}{*}{ Variabel } & \multirow{2}{*}{ Satuan } & \multicolumn{3}{c|}{ Alat Tangkap } & \multirow{2}{*}{ Rata-rata } \\
\cline { 3 - 6 } & & $\begin{array}{c}\text { Cantrang } \\
\text { (Dogol) }\end{array}$ & $\begin{array}{c}\text { Purse } \\
\text { Seine }\end{array}$ & Pancing & \\
\hline Ukuran GT & GT & 16,29 & 17,72 & 8,31 & 15,79 \\
\hline Biaya Operasional & $\begin{array}{c}\text { Juta } \\
\text { Rupiah }\end{array}$ & 18,80 & 13,80 & 7,04 & 15,63 \\
\hline Umur & Tahun & 44,45 & 44,53 & 36,31 & 43,47 \\
\hline Pendidikan & Tahun & 6,48 & 6,94 & 877 & 6,92 \\
\hline Pengalaman & Tahun & 24,04 & 24,83 & 16,54 & 23,38 \\
\hline
\end{tabular}




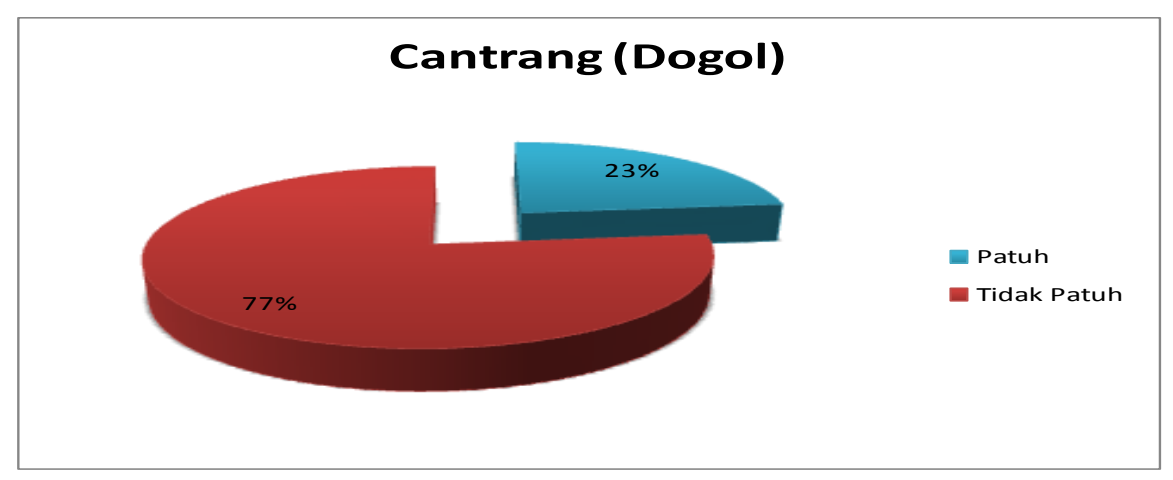

Gambar 1. Persentase kepatuhan nelayan cantrang (dogol)

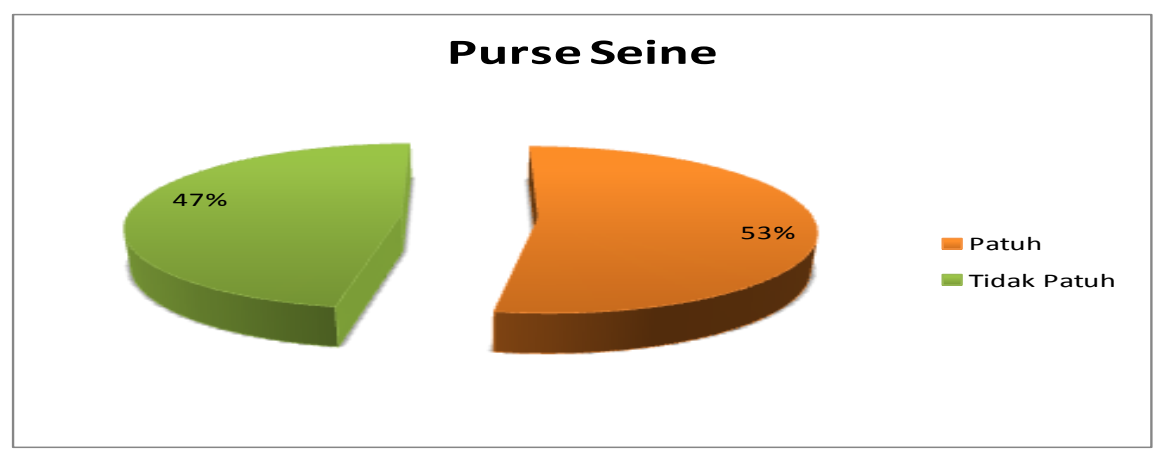

Gambar 2. Persentase kepatuhan nelayan purse seine

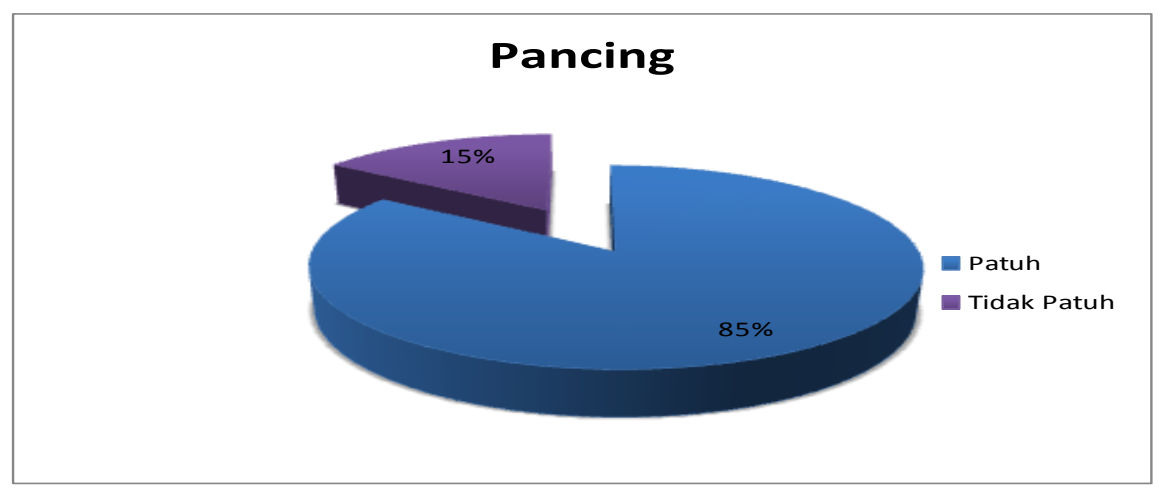

Gambar 3. Persentase kepatuhan nelayan pancing

\subsection{Analisis Peubah Dalam Kegiatan Illegal Fishing}

Untuk mengetahui kecendrungan nelayan melakukan kegiatan illegal fishing, dilakukan analisis regresi dengan model Logit, dimana variabel dependen $\mathrm{Y}=1$ Jika melakukan illegal fishing dan $\mathrm{Y}=0$ jika taat pada peraturan. Adapun variabel - variabel bebas yang diduga mempengaruhi probabilitas responden melakukan illegal fishing adalah biaya melaut ( $\left.\mathrm{X}_{\text {biayaops }}\right)$, ukuran GT sebenarnya $\left(\mathrm{X}_{\mathrm{GT}}\right)$, variabel sosial ekonomi : umur (XUMUR), pendidikan (X $\left.\mathrm{X}_{\mathrm{PDD}}\right)$, dan pengalaman $\left(\mathrm{X}_{\mathrm{dPENG}}\right)$, dan jenis alat tangkap $\left(\mathrm{X}_{\text {dAlatTAngkap }}\right)$. Berikut formula logit model dalam penelitian ini :

$$
Y=\beta_{0}+\beta_{1} X_{\text {BiayaOps }}+\beta_{2} X_{G T}+\beta_{3} X_{U M U R}+\beta_{4} X_{P D D}+\beta_{5} X_{P E N G}+\beta_{6} X_{\text {dAlatTangkap }}
$$

dimana : 
BiayaOps : Biaya operasional melaut (Juta rupiah/trip)

GT : Ukuran GT sebenarnya (GT)

Umur : Umur responden (dalam

Tahun)

PDD : Lamanya pendidikan yang ditempuh responden (dalam Tahun)

PENG : Lamanya pengalaman responden menjadi nelayan (dalam Tahun)

dAlatTangkap : Variabel dummy alat tangkap, diberi nilai 1 jika alat tangkap yang digunakan responden adalah cantrang (dogol), diberi nilai 2 jika alat tangkap yang digunakan purse seine, dan nilai 3 jika alat tangkap yang digunakan adalah pancing rawai.

Analisis regresi dengan model logit dilakukan pada 2 model, dimana model 1 tidak memasukan variabel sosial ekonomi/sosek (umur, pendidikan dan pengalaman) dan model 2 memasukan variabel sosek. Hasil analisis regresi logit dapat dilihat pada Tabel 2. Tabel 2 memperlihatkan hasil analisis regresi logit dari dua model berbeda. Pada model 1 variabel yang berpengaruh nyata adalah variabel biaya operasional ( $\mathrm{x}_{\mathrm{ops}}$ ) dan variabel dummy alat tangkap
( $\left.\mathrm{X}_{\text {dAlatTAngkap}}\right)$ dengan nilai probability ( $\mathrm{p}$ value) sebesar 0,02 dan 0,00 yang berarti signifikan pada taraf nyata $a=5 \%$. Tanda koefisien variabel biaya operasional adalah negatif dan nilai odds ratio sebesar 0,92, hal ini berarti responden dengan biaya operasional yang lebih rendah mempunyai kecendrungan melakukan kegiatan illegal fishing 0,92 kali lebih tinggi dibadingkan dengan responden yang biaya melautnya lebih tinggi. Tanda koefisien variabel dummy alat tangkap juga negatif dan mempunyai nilai odds ratio sebesar 0,14 , hal ini berarti responden yang menggunakan alat tangkap cantrang mempunyai kecendrungan 0,14 kali lebih tinggi melakukan kegiatan illegal fishing dibandingkan dengan nelayan yang menggunakan alat tangkap purse seine, dan nelayan yang menggunakan alat tangkap purse seine mempunyai kecendrungan melakukan illegal fishing 0,14 kali lebih tinggi dibandingkan dengan responden yang menggunan alat tangkap pancing rawai (cantrang $>$ purse seine $>$ pancing rawai).

Tabel 2. Analisis logit untuk illegal fishing

\begin{tabular}{|c|c|c|c|c|c|c|}
\hline \multirow{2}{*}{ Variabel } & \multicolumn{3}{|c|}{$\begin{array}{c}\text { Model } 1 \\
\text { (tanpa variabel Sosek) }\end{array}$} & \multicolumn{3}{|c|}{$\begin{array}{c}\text { Model 2 } \\
\text { (dengan variabel Sosek) }\end{array}$} \\
\hline & Koefisien & $\begin{array}{l}\text { Odds } \\
\text { Ratio }\end{array}$ & P-value & Koefisien & $\begin{array}{l}\text { Odds } \\
\text { Ratio }\end{array}$ & P-value \\
\hline Konstanta & 5,22 & & 0,00 & $-1,49$ & 0,23 & 0,55 \\
\hline $\mathrm{X}_{\text {biayaops }}$ & $-0,08$ & 0,92 & $0,02^{*}$ & $-0,07$ & 0,93 & $0,10^{* *}$ \\
\hline $\mathrm{X}_{\mathrm{GT}}$ & $-0,03$ & 0,97 & 0,35 & $-0,06$ & 0,94 & $0,09 * *$ \\
\hline Xumur & & & & 0,29 & 1,34 & $0,00^{*}$ \\
\hline $\mathrm{X}_{\mathrm{PDD}}$ & & & & $-0,15$ & 0,86 & 0,25 \\
\hline XenG & & & & $-0,20$ & 0,82 & $0,02^{*}$ \\
\hline X XAlatTAngkap & $-1,95$ & 0,14 & $0,00^{*}$ & $-1,77$ & 0,17 & $0,00^{*}$ \\
\hline$R_{M C F}^{2}$ & \multicolumn{3}{|c|}{0,19} & \multicolumn{3}{|c|}{0,30} \\
\hline LR statistic & \multicolumn{3}{|c|}{26,56} & \multicolumn{3}{|c|}{42,63} \\
\hline Prob (PR Statistic) & \multicolumn{3}{|c|}{0,00} & \multicolumn{3}{|c|}{0,00} \\
\hline
\end{tabular}

* Signifikan pada $a=5 \%$, ** Signifikan pada $a=10 \%$

Selanjutnya untuk menguji hipotesis nul model 1, apakah semua variabel penjelas secara bersama-sama tidak mempengaruhi keputusan melakukan kegiatan perdagangan ilegal maka digunakan uji statistik Likelihood Ratio (LR statistic). Nilai LR statistik hasil analisis adalah 26,56 dengan probability dari LR statistik adalah 0,00 (kurang dari $\mathrm{a}=5 \%$ ), oleh karena itu $\mathrm{H}_{0}$ ditolak, artinya bahwa semua variabel bebas secara bersama-sama mempengaruhi keputusan responden untuk melakukan kegiatan illegal fishing atau tidak. Untuk 
mengetahui kebaikan model (goodness of fit) dari model 1 digunakan koefisien determinasi $M c$ Fadden $\left(R_{M C F}^{2}\right)$, nilai $R_{M C F}^{2}$ sebesar 0,19 artinya hanya $19 \%$ model ini diterangkan oleh variabelvariabel biaya operasional, ukuran GT sebenarnya dan alat tangkap yang digunakan, sedangkan $91 \%$ oleh variabel lainnya. Sehingga untuk model pertama ini bisa dikatakan kurang baik, oleh karena itu pada model kedua dimasukan variabel-variabel sosial ekonomi.

Hasil analisis logit model kedua pada Tabel 2, dapat dilihat bahwa variabel - variabel yang berpengaruh nyata adalah biaya melaut ( $\mathrm{X}_{\text {biayaops }}$ ) dan ukuran GT kapal $\left(\mathrm{X}_{\mathrm{GT}}\right)$ yang signifikan pada taraf nyata $a=10 \%$ (p-value : 0,10 dan 0,09) , sedangkan variabel yang berpengaruh nyata pada taraf nyata $a=5$ $\%$ adalah variabel umur ( $\mathrm{p}$-value : 0,00 ), variabel pengalaman ( $p$-value : 0,02$)$ dan variabel dummy alat tangkap ( $\mathrm{p}$-value : $0,00)$. Variabel koefisien biaya operasional ( $\left.\mathrm{X}_{\text {biayaops}}\right)$ bertanda negatif dan nilai odds ratio sebesar 0,93 artinya responden dengan biaya melaut lebih rendah kemungkinan untuk melakukan kegiatan illegal fishing 0,93 kali lebih besar daripada responden dengan biaya melaut tinggi. Koefisien vaiabel ukuran GT kapal (XGT) mempunyai tanda negatif dan nilai odd ratio sebesar 0,94, artinya bahwa semakin rendah ukuran GT kapal maka kecendrungan untuk melakukan kegiatan illegal fishing 0,94 kali dibandingkan dengan kapal dengan ukuran GT lebih tinggi. Hal tersebut dikarenakan kapal dengan ukuran GT tinggi jika melakukan kegiatan illegal seperti penurunan GT kapal pada surat izin akan lebih jelas terlihat dibandingkan kapal dengan ukutan GT yang lebih kecil. Koefisien variabel umur (X $\mathrm{X}_{\text {UMUR }}$ ) bertanda positif berarti dan dengan nilai odds ratio sebesar 1,34 , hal ini berarti responden yang mempunyai umur lebih tua 1,34 kali mempunyai kemungkinan melakukan tindakan illegal fishing dibandingkan dengan responden dengan umur yang lebih muda. Berdasarkan pengamatan di lapangan nelayan yang lebih muda lebih mau menerima saran mengenai kelangsungan usaha mereka dari petugas pengawas perikanan dibandingkan dengan nelayan yang lebih tua, alasanya karena selama ini mereka tidak pernah ditangkap oleh pihak yang berwajib. Variabel pengalaman ( $\mathrm{X}_{\mathrm{PENG}}$ ) mempunyai tanda negatif dan mempunyai nilai odds ratio sebesar 0,82 artinya bahwa responden dengan pengalaman lebih sedikit mempunyai kecendrungan untuk melakukan kegiatan illegal fishing 0,82 kali lebih banyak dibandingkan responden dengan pengalaman yang lebih lama. Kemudian variable yang berpengaruh nyata terakhir adalah variabel alat tangkap ( $\left.\mathrm{X}_{\text {dAlatTAngkap}}\right)$, nilai koefisien yang negatif dan nilai odds ratio sebesar 0,27 berarti bahwa responden yang menggunakan alat tangkap cantrang memiliki kemungkinan (probability) sebesar 0,17 kali lebih besar dibandingkan responden yang menggunakan alat tangkap purse seine, dan responden dengan alat tangkap purse seine memiliki kemungkinan 0,17 kali melakukan kegiatan ilegal dibandingkan nelayan dengan alat tangkap pancing rawai. Hal ini sesuai dengan kondisi lapangan dimana pada tahun 2010 persentasi nelayan dengan menggunakan alat tangkap cantrang adalah sebesar 92,23\% dari total alat tangkap yang ada di PPN Brondong,

Hasil uji statistik likelihood ratio (LR Statistik) adalah sebesar 42,63 dengan probability (PR Statistic) 0,00 dan berarti signifikan pada $a=5 \%$ sehingga $\mathrm{H}_{0}$ ditolak, artinya bahwa semua variabel bebas (biaya melaut, ukuran GT kapal sebenarnya, umur, pendidikan, pengalaman, dan alat tangkap) secara bersama-sama mempengaruhi keputusan responden untuk melakukan kegiatan illegal fishing atau tidak. Kemudian nilai koefisien determinasi Mc Fadden $\left(R_{M C F}^{2}\right)$ dari model 2 adalah sebesar 0,30 artinya bahwa hanya sebesar $30 \%$ model ini ditearngkan oleh variabel - variabel biaya melaut, ukuran GT kapal sebenarnya, alat tangkap dan variabel sosial ekonomi (umur, pendidikan, dan pengalaman). Nilai koefisien ini relatif rendah, akan tetapi apabila kita bandingkan dengan penelitian-penelitian yang menggunakan analisis regresi kualitatif memang nilai koefisien determinasinya rendah, seperti penelitian Yannis dan Antoniou (2007) dengan nilai $\rho^{2}$ (pseudo $\mathrm{R}^{2}$ ) sebesar 0,40 dan penelitian Lowasa et al (2011) nilai $\rho^{2}$ sebesar 0,18. Nilai $\rho^{2}$ juga biasa digunakan untutk melihat kebaikan regresi model logit (Henser dan Johnson 1981 diacu dalam Wielgus et al., 2003). 


\section{KESIMPULAN DAN SARAN}

Berdasarkan hasil analisis, maka penelitian analisis logit keputusan perilaku illegal fishing menyimpulkan:

(1) terdapat hubungan yang nyata antara biaya izin dan biaya operasional dan kecendrungan melakukan illegal fishing. Nilai koefisien $\mathrm{X}_{1}$ (biaya operasi) pada model 1 menunjukkan bahwa biaya operasional berpengaruh nyata terhadap biaya izin, artinya setiap kenaikan biaya operasional sebesar Rp. 1 juta maka akan menaikan biaya izin sebesar Rp. 31.240 , sedangkan variabel dummy bernilai negatif yaitu sebesar $-2,735$ artinya biaya izin illegal fishing lebih rendah daripada biaya izin kapal yang taat sebesar Rp. 2.735.000.

(2) Seiring dengan perkembangan kelembagaan pengawasan, penangkapan kapal illegal fishing yang terjadi saat ini lebih berorientasi pada kapal asing. Dalam kenyataannya banyak nelayan-nelayan kecil di berbagai daerah melakukan kegiatan ilegal. Penelitian yang dilakukan di Brondong Jawa Timur merupakan suatu potret yang dapat dikembangkan kembali dalam meneliti ketidaktaatan nelayan terhadap aturan perundangundangan.

Dari kesimpulan tersebut disarankan bahwa kasus ini masih perlu didalami karena secara sederhana dapat dibuktikan bahwa pelanggaran wilayah fishing ground dan perijinan, serta tidak sesuainya ukuran kapal penangkapan ikan antara ijin dengan ukuran sebenarnya merupakan fenomena yang perlu diteliti lebih jauh, karena penelitian belum menemukan korelasinya.

\section{DAFTAR PUSTAKA}

Direktur Jenderal Pengawasan Sumber Daya Kelautan dan Perikanan. 2009.

Hosmer D. W. dan S. Lemeshow.2000. Applied Logistic Regression $2^{\text {nd }}$ edition. New York. John Wiley and Sons, Inc.

Juanda, B. 2009. Ekonometrika : pemodelan dan pendugaan. IPB Press, Bogor.

Lowasa, A, D. Brennan, M. Czajkowski, A. Fischer, N. Hanley. L.Naiman. What can be Done to Reduce Illegal Fishing? An Investigation Using Choice Experiment in Serengeti, Tanzania. 13 $13^{\text {th }}$ Annual BIECON Conference "Resource Economics, Biodiversity Conservation and Development". Geneva.

[MRAG] Marine Resources Assessment Group. 2005. Review of Impacts of Illegal, Unreported and Unregulated Fishing on Developing Countries: Synthesis Report. UK Department. $17 \mathrm{p}$.

http://www.pipp.kkp.go.id/pipp2/kapala pi_index.html. diunduh pada tanggal 28 Oktober 2011.

Yannis, G dan C. Antoniou. 2007. A Mixed Logit Model for the Sensitivity Analysis of Greek drivers' Behavior towards Enforcement for Road Safety. European Transport n.37(2007): 62-67.

Wielgus J, Chadwik-Furman NE, Zeitouni N, Shechter M. 2003. Effect on Coral Reef Attribute Damage on Recreational Welfare. Marine Resource Economics (18): 225-237. 
Lampiran 1. Data karakteristik responden untuk analisis logit

\begin{tabular}{|c|c|c|c|c|c|c|c|}
\hline No. & $\mathbf{Y}$ & GT & $\begin{array}{c}\text { Biaya } \\
\text { Operasional } \\
\text { (dalam juta) }\end{array}$ & $\begin{array}{l}\text { UMUR } \\
\text { (Tahun) }\end{array}$ & $\begin{array}{c}\text { Pendidikan } \\
\text { (Tahun) }\end{array}$ & $\begin{array}{c}\text { Pengalaman } \\
\text { (Tahun) }\end{array}$ & $\begin{array}{c}\text { Dummy } \\
\text { Alat } \\
\text { Tangkap }\end{array}$ \\
\hline 1 & 1 & 17 & 2.76 & 45 & 9 & 22 & 2 \\
\hline 2 & 0 & 17 & 2.76 & 55 & 6 & 35 & 2 \\
\hline 3 & 0 & 17 & 2.71 & 48 & 6 & 32 & 2 \\
\hline 4 & 1 & 17 & 4.46 & 48 & 9 & 20 & 2 \\
\hline 5 & 1 & 24 & 3.05 & 48 & 6 & 32 & 2 \\
\hline 6 & 0 & 24 & 3.72 & 36 & 12 & 14 & 2 \\
\hline 7 & 1 & 24 & 2.71 & 31 & 9 & 6 & 2 \\
\hline 8 & 0 & 24 & 3.96 & 60 & 6 & 44 & 2 \\
\hline 9 & 1 & 24 & 2.95 & 58 & 6 & 42 & 2 \\
\hline 10 & 1 & 24 & 3.24 & 43 & 9 & 11 & 2 \\
\hline 11 & 1 & 24 & 3.24 & 47 & 12 & 20 & 2 \\
\hline 12 & 1 & 8 & 13.80 & 44 & 12 & 12 & 1 \\
\hline 13 & 1 & 8 & 34.48 & 48 & 9 & 30 & 1 \\
\hline 14 & 1 & 8 & 12.89 & 43 & 9 & 14 & 1 \\
\hline 15 & 1 & 8 & 15.20 & 45 & 6 & 19 & 1 \\
\hline 16 & 1 & 13 & 15.20 & 43 & 12 & 21 & 1 \\
\hline 17 & 1 & 13 & 14.48 & 43 & 9 & 14 & 1 \\
\hline 18 & 1 & 13 & 15.20 & 42 & 9 & 13 & 1 \\
\hline 19 & 1 & 13 & 15.20 & 54 & 6 & 38 & 1 \\
\hline 20 & 1 & 13 & 13.80 & 43 & 9 & 24 & 1 \\
\hline 21 & 1 & 13 & 15.20 & 51 & 6 & 35 & 1 \\
\hline 22 & 1 & 7 & 10.64 & 45 & 9 & 16 & 1 \\
\hline 23 & 1 & 7 & 14.79 & 42 & 12 & 20 & 1 \\
\hline 24 & 1 & 8 & 10.81 & 42 & 6 & 16 & 1 \\
\hline 25 & 0 & 6 & 8.28 & 40 & 9 & 21 & 3 \\
\hline 26 & 0 & 6 & 7.05 & 46 & 6 & 30 & 3 \\
\hline 27 & 0 & 6 & 8.65 & 43 & 9 & 24 & 3 \\
\hline 28 & 0 & 6 & 7.48 & 33 & 12 & 11 & 3 \\
\hline 29 & 1 & 6 & 7.58 & 29 & 9 & 5 & 3 \\
\hline 30 & 1 & 6 & 8.85 & 40 & 9 & 21 & 3 \\
\hline 31 & 0 & 12 & 8.65 & 34 & 6 & 13 & 3 \\
\hline 32 & 0 & 12 & 5.93 & 29 & 9 & 10 & 3 \\
\hline 33 & 0 & 12 & 5.30 & 40 & 9 & 21 & 3 \\
\hline 34 & 0 & 12 & 6.09 & 37 & 9 & 18 & 3 \\
\hline 35 & 0 & 6 & 5.87 & 38 & 9 & 19 & 3 \\
\hline 36 & 0 & 12 & 7.19 & 33 & 12 & 8 & 3 \\
\hline 37 & 0 & 6 & 4.61 & 30 & 6 & 14 & 3 \\
\hline 38 & 1 & 8 & 16.53 & 43 & 9 & 24 & 1 \\
\hline 39 & 1 & 15 & 18.59 & 40 & 6 & 24 & 1 \\
\hline 40 & 0 & 16 & 26.38 & 30 & 6 & 14 & 1 \\
\hline
\end{tabular}




\begin{tabular}{|c|c|c|c|c|c|c|c|}
\hline No. & $\mathbf{Y}$ & GT & $\begin{array}{c}\text { Biaya } \\
\text { Operasional } \\
\text { (dalam juta) }\end{array}$ & $\begin{array}{c}\text { UMUR } \\
\text { (Tahun) }\end{array}$ & $\begin{array}{c}\text { Pendidikan } \\
\text { (Tahun) }\end{array}$ & $\begin{array}{c}\text { Pengalaman } \\
\text { (Tahun) }\end{array}$ & $\begin{array}{c}\text { Dummy } \\
\text { Alat } \\
\text { Tangkap }\end{array}$ \\
\hline 41 & 1 & 29 & 20.81 & 45 & 6 & 29 & 1 \\
\hline 42 & 1 & 15 & 13.96 & 65 & 6 & 49 & 1 \\
\hline 43 & 1 & 16 & 18.77 & 45 & 6 & 29 & 1 \\
\hline 44 & 1 & 16 & 17.85 & 53 & 6 & 37 & 1 \\
\hline 45 & 1 & 16 & 13.96 & 56 & 5 & 41 & 1 \\
\hline 46 & 0 & 14 & 19.05 & 32 & 5 & 12 & 1 \\
\hline 47 & 0 & 28 & 24.33 & 34 & 4 & 13 & 2 \\
\hline 48 & 0 & 16 & 16.6 & 41 & 4 & 27 & 1 \\
\hline 49 & 0 & 14 & 18.85 & 39 & 4 & 21 & 2 \\
\hline 50 & 0 & 16 & 24.66 & 45 & 6 & 20 & 2 \\
\hline 51 & 0 & 15 & 27.9 & 43 & 6 & 21 & 1 \\
\hline 52 & 0 & 14 & 25.37 & 39 & 6 & 19 & 2 \\
\hline 53 & 0 & 11 & 15.96 & 51 & 6 & 35 & 2 \\
\hline 54 & 0 & 29 & 25 & 50 & 6 & 34 & 2 \\
\hline 55 & 0 & 25 & 24.26 & 44 & 6 & 28 & 2 \\
\hline 56 & 1 & 14 & 15.96 & 42 & 4 & 28 & 1 \\
\hline 57 & 1 & 16 & 18.15 & 42 & 4 & 18 & 1 \\
\hline 58 & 1 & 15 & 22.17 & 45 & 4 & 31 & 1 \\
\hline 59 & 1 & 16 & 16.53 & 47 & 6 & 31 & 1 \\
\hline 60 & 1 & 16 & 14.1 & 41 & 6 & 25 & 1 \\
\hline 61 & 1 & 27 & 24.26 & 41 & 6 & 25 & 1 \\
\hline 62 & 1 & 29 & 24.33 & 44 & 6 & 26 & 1 \\
\hline 63 & 1 & 28 & 24.33 & 46 & 6 & 17 & 1 \\
\hline 64 & 0 & 11 & 11.69 & 30 & 6 & 14 & 2 \\
\hline 65 & 1 & 28 & 26.69 & 44 & 6 & 18 & 1 \\
\hline 66 & 1 & 27 & 19.32 & 42 & 6 & 20 & 1 \\
\hline 67 & 1 & 28 & 29.22 & 45 & 6 & 9 & 1 \\
\hline 68 & 1 & 16 & 13.96 & 40 & 6 & 15 & 1 \\
\hline 69 & 1 & 15 & 13.96 & 45 & 6 & 20 & 1 \\
\hline 70 & 1 & 14 & 17.35 & 56 & 6 & 40 & 2 \\
\hline 71 & 1 & 11 & 13.99 & 49 & 6 & 29 & 2 \\
\hline 72 & 1 & 14 & 18.13 & 50 & 6 & 34 & 2 \\
\hline 73 & 0 & 13 & 17.35 & 58 & 6 & 42 & 2 \\
\hline 74 & 0 & 15 & 18.56 & 51 & 6 & 35 & 1 \\
\hline 75 & 0 & 16 & 17.07 & 31 & 6 & 15 & 1 \\
\hline 76 & 0 & 16 & 14.37 & 50 & 6 & 34 & 1 \\
\hline 77 & 0 & 16 & 13.45 & 33 & 6 & 17 & 1 \\
\hline 78 & 0 & 16 & 15.41 & 29 & 6 & 13 & 1 \\
\hline 79 & 1 & 14 & 16.2 & 43 & 6 & 27 & 2 \\
\hline 80 & 0 & 15 & 17.95 & 33 & 6 & 17 & 2 \\
\hline 81 & 1 & 14 & 15 & 42 & 6 & 15 & 2 \\
\hline 82 & 1 & 14 & 15.61 & 32 & 6 & 10 & 2 \\
\hline
\end{tabular}




\begin{tabular}{|c|c|c|c|c|c|c|c|}
\hline No. & $\mathbf{Y}$ & GT & $\begin{array}{c}\text { Biaya } \\
\text { Operasional } \\
\text { (dalam juta) }\end{array}$ & $\begin{array}{l}\text { UMUR } \\
\text { (Tahun) }\end{array}$ & $\begin{array}{c}\text { Pendidikan } \\
\text { (Tahun) }\end{array}$ & $\begin{array}{c}\text { Pengalaman } \\
\text { (Tahun) }\end{array}$ & $\begin{array}{c}\text { Dummy } \\
\text { Alat } \\
\text { Tangkap }\end{array}$ \\
\hline 83 & 1 & 13 & 15.96 & 47 & 6 & 31 & 1 \\
\hline 84 & 1 & 16 & 18.15 & 47 & 6 & 21 & 1 \\
\hline 85 & 1 & 6 & 11.69 & 55 & 6 & 39 & 1 \\
\hline 86 & 1 & 16 & 19.05 & 45 & 6 & 9 & 1 \\
\hline 87 & 0 & 16 & 18.56 & 45 & 9 & 26 & 2 \\
\hline 88 & 0 & 20 & 17.07 & 54 & 6 & 38 & 2 \\
\hline 89 & 0 & 22 & 25.37 & 34 & 12 & 12 & 2 \\
\hline 90 & 0 & 20 & 13.45 & 31 & 9 & 12 & 2 \\
\hline 91 & 1 & 6 & 17.13 & 60 & 6 & 44 & 1 \\
\hline 92 & 1 & 6 & 11.69 & 52 & 5 & 37 & 2 \\
\hline 93 & 1 & 15 & 18.77 & 48 & 6 & 32 & 2 \\
\hline 94 & 1 & 14 & 17.85 & 43 & 6 & 20 & 2 \\
\hline 95 & 0 & 18 & 19.05 & 45 & 9 & 26 & 2 \\
\hline 96 & 0 & 22 & 23.75 & 43 & 9 & 24 & 1 \\
\hline 97 & 0 & 20 & 16.6 & 49 & 9 & 30 & 1 \\
\hline 98 & 1 & 14 & 17.85 & 37 & 6 & 15 & 2 \\
\hline 99 & 1 & 29 & 28.24 & 55 & 6 & 39 & 1 \\
\hline 100 & 1 & 29 & 26.38 & 39 & 6 & 9 & 1 \\
\hline 101 & 1 & 25 & 24.33 & 49 & 3 & 36 & 1 \\
\hline 102 & 1 & 11 & 24.89 & 45 & 1 & 34 & 1 \\
\hline 103 & 1 & 13 & 15.96 & 47 & 6 & 31 & 1 \\
\hline 104 & 0 & 22 & 29.22 & 34 & 6 & 18 & 1 \\
\hline 105 & 0 & 22 & 27.61 & 38 & 6 & 5 & 1 \\
\hline
\end{tabular}


Lampiran 2. Analisis descriptive statistics karaktersitik responden

Descriptive Statistics: GT, Biaya Operas, UMUR (Tahun), Pendidikan (, ...

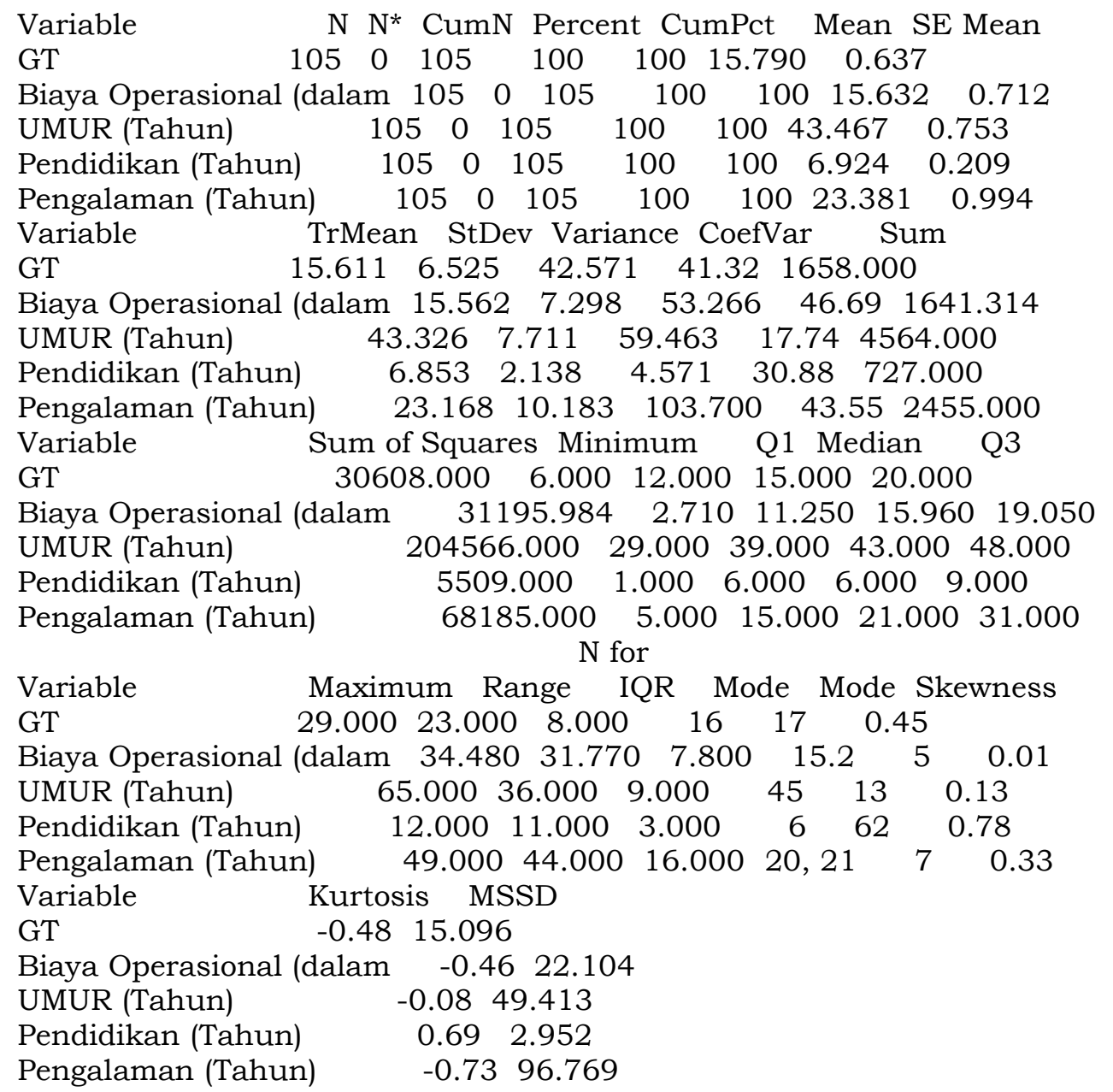


Lampiran 3. Output analisis model 1 logit dengan perangkat lunak eviews

MODELl 1

Dependent Variable: $Y$

Method: ML - Binary Logit (Quadratic hill climbing)

Date: 11/01/11 Time: 13:21

Sample: 1105

Included observations: 105

Convergence achieved after 4 iterations

QML (Huber/White) standard errors \& covariance

\begin{tabular}{lrlrr}
\hline \hline \multicolumn{1}{c}{ Variable } & Coefficient & Std. Error & z-Statistic & Prob. \\
\hline \hline \multicolumn{1}{c}{ C } & 5.220591 & 1.141068 & 4.575179 & 0.0000 \\
BIAYA_OPS & -0.078026 & 0.034723 & -2.247108 & 0.0246 \\
GT & -0.028786 & 0.030559 & -0.941969 & 0.3462 \\
\multicolumn{1}{c}{ DALTANG } & -1.947289 & 0.398672 & -4.884434 & 0.0000 \\
\hline \hline McFadden R-squared & 0.186924 & Mean dependent var & 0.590476 \\
S.D. dependent var & 0.494104 & S.E. of regression & 0.438387 \\
Akaike info criterion & 1.176583 & Sum squared resid & 19.41050 \\
Schwarz criterion & 1.277687 & Log likelihood & -57.77063 \\
Hannan-Quinn criter. & 1.217552 & Deviance & 115.5413 \\
Restr. deviance & 142.1038 & Restr. log likelihood & -71.05190 \\
LR statistic & 26.56255 & Avg. log likelihood & -0.550196 \\
Prob(LR statistic) & 0.000007 & & 105 \\
\hline \hline Obs with Dep=0 & \multirow{2}{*}{43} & Total obs & \\
Obs with Dep=1 & 62 & & \\
\hline \hline
\end{tabular}


Lampiran 4. Output analisis model 2 logit dengan perangkat lunak eviews

MODEL 2

Dependent Variable: Y

Method: ML - Binary Logit (Quadratic hill climbing)

Date: 11/01/11 Time: 00:20

Sample: 1105

Included observations: 105

Convergence achieved after 5 iterations

QML (Huber/White) standard errors \& covariance

\begin{tabular}{|c|c|c|c|c|}
\hline Variable & Coefficient & Std. Error & $z$-Statistic & Prob. \\
\hline $\mathrm{C}$ & -1.486208 & 2.468500 & -0.602069 & 0.5471 \\
\hline BIAYA_OPS & -0.069661 & 0.042782 & -1.628275 & 0.1035 \\
\hline $\mathrm{GT}$ & -0.063155 & 0.037244 & -1.695719 & 0.0899 \\
\hline UMUR & 0.290490 & 0.092684 & 3.134196 & 0.0017 \\
\hline PDD & -0.151337 & 0.131355 & -1.152126 & 0.2493 \\
\hline PENG & -0.196323 & 0.084369 & -2.326954 & 0.0200 \\
\hline DALTANG & -1.774484 & 0.421866 & -4.206269 & 0.0000 \\
\hline McFadden R-squared & 0.299977 & & 0.590476 \\
\hline S.D. dependent var & 0.494104 & \multicolumn{2}{|c|}{ S.E. of regression } & 0.409474 \\
\hline Akaike info criterion & 1.080723 & \multicolumn{2}{|c|}{ Sum squared resid } & 16.43158 \\
\hline Schwarz criterion & 1.257654 & \multicolumn{2}{|c|}{ Log likelihood } & -49.73797 \\
\hline Hannan-Quinn criter. & 1.152419 & \multicolumn{2}{|c|}{ Deviance } & 99.47594 \\
\hline Restr. deviance & 142.1038 & \multicolumn{2}{|c|}{ Restr. log likelihood } & -71.05190 \\
\hline LR statistic & 42.62786 & \multicolumn{2}{|c|}{ Avg. log likelihood } & -0.473695 \\
\hline Prob(LR statistic) & 0.000000 & & & \\
\hline Obs with Dep $=0$ & 43 & \multicolumn{2}{|l|}{ Total obs } & 105 \\
\hline Obs with Dep=1 & 62 & & & \\
\hline
\end{tabular}

